\title{
Faculty Awareness and Utilization of the Essential Electronic Agricultural Library for Teaching and Research: A Study of Academic Staff in the University of Calabar, Nigeria
}

\author{
Nkoyo B. Edem \\ Library Department, University of Calabar, Calabar, Nigeria \\ Email address: \\ nkyedem@gmail.com
}

\section{To cite this article:}

Nkoyo B. Edem. Faculty Awareness and Utilization of the Essential Electronic Agricultural Library for Teaching and Research: A Study of Academic Staff in the University of Calabar, Nigeria. Education Journal. Vol. 5, No. 3, 2016 pp. 33-38.

doi: $10.11648 /$ j.edu.20160503.11

Received: March 10, 2016; Accepted: March 18, 2016; Published: May 26, 2016

\begin{abstract}
This study reports on a survey conducted to explore the awareness and extent of utilization of The Essential Electronic Agricultural Library (TEEAL) database resources by academic staff at the faculty of Agriculture, University of Calabar, Nigeria. Structured Questionnaire was designed and used for data collection. Eighty copies of the questionnaire were randomly distributed to respondents in their offices; 60 copies of these were retrieved and used for data analysis (with $75.0 \%$ response rate). The findings of the study indicate that although vast majority $(88.3 \%$ ) of academic staff in the faculty of Agriculture are aware of TEEAL database resources, their utilization is rather low (46.7\%) in teaching and research, the frequency of usage is equally low, as most $(46.7 \%)$ respondents use these databases "occasionally". From the findings of the study, most respondents used TEEAL abstracts for research and publication (80.0\%), for better research output (53.3\%) for insights to various topics for lectures $(50.0 \%)$ and keep abreast with current trends in the field of study $(50.0 \%)$. Major factors that impede awareness and utilization of TEEAL databases by academic staff of the faculty of Agriculture, University of Calabar, Nigeria include lack of awareness of the available databases by the university library, lack of access to TEEAL databases in the University library, lack of time to spend in searching TEEAL databases in the Library and inadequate information skills to use TEEAL, and improper orientation on the use.
\end{abstract}

Keywords: Electronic Libraries, TEEAL Databases, E-resources, University Library, Offline Databases, Academic Staff

\section{Introduction}

The emergence of information and communication Technology (ICT) has led to the development of electronic libraries in universities around the world. This has brought a wider access to information to users for teaching, learning and research beyond their immediate academic environment. University libraries in Nigeria are not left out in this global trend to provide quick and timely access to electronic resources to promote scholarship in teaching, learning and research. According to Edem (2015), ICT has added value to effective research productivity in Nigerian Tertiary institutions. This development as observed by Ani, Esin and Edem (2005), has created a shift from traditional information environment to an electronic environment such as computer use, internet use, CD-ROM use, online services as well as online databases. In the digital age, Xie and Joo (2011) have opined that "the emergence of internet makes electronic information resources more accessible for end users" particularly in the academic environment. Both the students and faculty members find the resources very useful in meeting their research needs. The information seeking behavior of academic staff in universities is now shifted in favour of usage of electronic resources than the traditional printed resources. This is essentially attributed to a number of factors which include awareness, ease of access, efficiency, currency, cost effectiveness among others in developing countries, with the inability of the management of the 
universities and librarians to meet up with the challenges of regular subscriptions of electronic journals, online databases due to general financial constraints. Utilization of these databases / electronic resources becomes a challenge to the academic staff in their quest for quality teaching and research in the globally competitive knowledge economy.

Electronic resources according to Aina (2012) promote resource sharing that could be supplemented with the printed resources. In a study conducted on professional development by Aina (2012), identified the negative attitude of lecturers and students in the use of electronic databases, for effective research output and admits an "aggressive training program" for staff and students as well as "self development" in ICT skills to be able to compete in any academic community. In Nigeria, online databases are electronic resources that users should be aware and be able to utilize them effectively for research/teaching. The aim of this study therefore is to promote a wider orientation on the awareness and utilization of online databases (e.g TEEAL) in order to encourage excellence in teaching/ research in Nigerian Universities. Since the cost of subscriptions of relevant online databases (e.g AGORA, HINARI) by individual university is relatively high, some universities have resorted to using the Essential Electronic Agricultural Library (TEEAL), otherwise known as "library in a box". This is a full -text digital library of over 200 agricultural journals made available at low cost to institutions in eligible low income countries. It is an offline tool - no internet or phone line required. It can be shared on a local area network (LAN) or use on a standalone PC. The journal coverage starts in the then 1990's and is updated annually. TEEAL has a searchable database of citations from CAB abstract, BIOSIS, ECONLIT and PUBMED (scientific databases).

TEEAL features an easy to use interface that allows you to quickly search for save and print citations. Information about TEEAL covers many areas like: Aquaculture, Economics and Rural development, food science and Nutrition. Others are

- Microbiology

- Sustainable Agriculture

- Crop and soil science

- Natural resources management

- Plant protection

- Veterinary medicine

It will interest you to note that efforts are being made by the university management, University of Calabar, to procure more databases to assist in teaching and learning. Additionally, various national workshops have been organized to train librarians on how to organize user education/ training to their library users on awareness, access and usage of the acquired database. Information Training and Outreach Centre for Africa (ITOCA) organized a training programme in 2011 in the use of online databases (AGORA, HINARI and TEEAL etc) in Abeokuta, Nigeria, in which some librarians were sent on an intensive training on access and use of current online databases in Nigerian Universities. In view of the importance of utilization of online / offline databases in teaching/ research, the present study would investigate the awareness and extent of utilization of TEEAL by academic staff in faculty of Agriculture, University of Calabar, Nigeria.

\subsection{An Overview of Faculty of Agriculture, Forestry \& Wildlife Resources Management}

The present Faculty of Agriculture, Forestry and Wildlife Resources Management was established in 1980 as Faculty of Agriculture with a single department of Agriculture. This department expanded over the years to additional six departments which include the following: Forestry, Soil science, Animal Science, Crop Science, Agric Economics and Extension. In 2002, the single department was renamed Faculty of Agriculture, Forestry and Wildlife Resources Management. The Faculty focuses on research teaching and extension services with fast forest resources of Cross River State. The provision of print and non-print resources for academics gears to facilitate effective utilization for teaching and learning. Efforts are being made by the university to procure more databases to enhance effective usage in Nigerian universities. Additionally, various national workshops have been organized to train librarians on how to organize user education / training to their library users on awareness and utilization of the acquired databases.

\subsection{Literature Review}

A lot of studies have been conducted to investigate the provision of electronic resources to users for teaching and research particularly in Nigerian universities (Edem and Ani 2015; Chukwusa, 2015; Madhusudan, 2010; Lawal and Lawal 2015). Edem and Ani (2015) studied the development of electronic libraries in Nigerian universities and found out that all responding universities have developed their electronic libraries and varieties of electronic resources are accessible in those libraries, the most popular ones are ejournals online and offline databases. Their major factors that affect effective development of electronic libraries in Nigerian universities are frequent power outage and poor attitude of university management in the area of funding. The study concluded that development of electronic libraries in universities around the world has brought a wider access to information for users for teaching and research beyond their immediate academic environment and Nigerian universities must not be left out. The paper makes advocacy for the need to redress these problems as appropriate. Chukwusa (2015) determined electricity generation factor in the use of electronic resources in some selected university libraries in Nigeria. Result of study indicated that, there is no significant relationship between adequate power supply and limited access to the e-resources in the libraries. Access to the electronic resources is limited mainly due to the problem of electricity. Finally, the researcher posits that there is a significant relationship between the challenges to resources usage and provision of effective and efficient services in the libraries. One of the major recommendations is that librarians and library authorities must give priority attention to 
information technology, by making sure of adequate supply of electricity is provided to libraries especially when they are to continue in the business of providing information to the public and remain the main access point for researchers, students and other users.

Lawal and Lawal 2015 investigated the factors of the accessibility of databases among undergraduate students of Umaru Musa Yaradua, katsina, Nigeria. One findings of the study was that information awareness on the accessibility of databases among undergraduate students was inadequate and this affects the accessibility of databases. The paper discusses the need to increase awareness on databases subscription in the university library. The researcher posit that awareness and accessibility will increase the use of databases, whether online or offline. He recommended regular training of academic staff on updating their knowledge of the many sources, and access to databases from the university library. In addition to that, there should be an improvement on the provision of internet facilities on faculty's library.

Ani and Edem (2012) reported a survey conducted to explore the extent of access and use of online databases by academic staff in the University of Calabar, Nigeria. The findings of the study indicated that although vast majority $(96.3 \%)$ of the academic staff are accessing and using relevant online databases in teaching / research, the frequency of usage is rather low, as most (48.1\%) respondents used these databases "occasionally." From the findings, their major factors that impede access and use of online databases by academics in the university include non subscription of relevant online databases by the university library, cost of access and usage, lack of access to relevant databases and lack of inadequate internet skills for proper access in the university library. Analyzing and evaluating the use of electronic resources, a study conducted by Bhatt and Rana (2011) revealed that, the utilization of electronic resources by academics improved their professional competencies. Egberongbe (2011) found out in a study of use and impact of electronic resources that the majority of scholars were not trained in the use of e- resources. The study revealed that the level of IT skills among lecturers, scholars and library staff was low. Informal methods of training; one on one consultations, was used to inform users. However, a report by Forster, Heppensta, Lazarz and Baroug (2008) have revealed a low level of access and use of electronic resources by academic staff in Nigerian universities which is affecting their research and teaching. Bashorunh, Tunji and Adisa (2011) noted that the reasons for low frequency in utilizing electronic resources by academics include lack of time, lack of electronic resources awareness, power outage, in effective communication channels, slow net work and inadequate Information and Communication Technology (ICT), lack of training and lack of adequate power supply.

\section{Objective of the Study}

The main objective of this study is to investigate the awareness and extent of utilization of the Essential Electronic
Agricultural Library (TEEAL) database by the academic staff for research and teaching at the faculty of Agriculture, University of Calabar, Nigeria. The study would explore the following specific objectives:

1. To find out if academic staff at the faculty of Agriculture are aware of TEEAL database in the University Library.

2. To determine the extent of utilization of TEEAL database by academic staff in faculty of Agriculture, UNICAL.

3. To determine the frequency of utilization of TEEAL by academic staff for their research and teaching.

4. To find out the opinion of academic staff on assessment of TEEAL databases for research and teaching.

5. To determine different factors that impedes the utilization by academics for teaching and research.

\section{Research Methodology}

Quantitative research was used for the study with survey as the research method. Structured questionnaire was designed and use for data collection. Academic staff from Faculty of Agriculture, Forestry and Wildlife Resources Management, University of Calabar, Nigeria were used as respondents for the study; eighty (80) copies of the questionnaire were randomly distributed to the respondents in their offices; 60 copies of the questionnaire retrieved and used for data analysis (with $75.0 \%$ respondent rate).

\section{Results and Discussion}

The results of the study are presented and discussed under each of the stated research objectives.

The respondents were asked to indicate their demographic characteristics as presented below.

Table 1. Percentage Distribution of respondents by some selected Demographic characteristics in the faculty of Agriculture (Rank, sex, and department).

\begin{tabular}{lll}
\hline Rank & Frequency & Percentage \\
\hline Asst. Lecturer & 9 & 15.0 \\
Lecturer II & 10 & 16.8 \\
Lecturer I & 17 & 28.3 \\
Senior lecturer & 11 & 18.3 \\
Asso. Professor & 5 & 8.3 \\
Professor & 8 & 13.3 \\
Gender & & \\
Male & 45 & 75.0 \\
Female & 15 & 25.0 \\
Department & & \\
Forestry & 13 & 21.7 \\
Soil science & 12 & 20.0 \\
Animal science & 10 & 16.7 \\
Crop science & 14 & 23.3 \\
Agric economics & 6 & 10.0 \\
Agricultural extension & 5 & 8.3 \\
Total & 60 & 100.0 \\
\hline
\end{tabular}


Entries in table 1 showed the percentage distribution of respondents by some selected demographic characteristics (rank, gender and department) of the academic staff in the faculty of agriculture, the results are presented per department from Assistant lecturer to professor. The male $(75.0 \%)$ respondents outnumbered the females $(25.0 \%)$ in the faculty under study. The result implies that male lecturers are more educational developed in the faculty in the utilization of re-resources than the female counterparts for teaching and research. Presently, more females are catching up with the trends for effective research. A total of six departments were used for the study. The result showed that Crop Science $(23.3 \%)$ had the highest respondents.

Table 2. Awareness of TEEAL in the University of Calabar Library.

\begin{tabular}{lll}
\hline Academic staff & Aware\% & Not Aware\% \\
\hline Asst. Lecturer & $7(11.7)$ & $2(3.3)$ \\
Lecturer II & $8(13.3)$ & $2(3.3)$ \\
Lecturer I & $15(25.0)$ & $2(3.3)$ \\
Senior lecturer & $10(16.7)$ & $1(1.8)$ \\
Asso. professor & $5(8.3)$ & $-(0.0)$ \\
Professor & $8(13.3)$ & $-(0.0)$ \\
Total & $53(88.3)$ & $7(11.7)$ \\
\hline
\end{tabular}

Respondents were asked to indicate if they are aware of TEEAL databases in the university of Calabar Library. The study on table 2 revealed that majority of the respondents in the Faculty of Agriculture are aware $(88.3 \%)$ of TEEAL databases only a few (11.7\%) indicated their non-awareness of the databases in the University of Calabar Library.

\subsection{Extent of Utilization of TEEAL Databases in the University of Calabar Library}

In this study, the respondents were asked to indicate their extent of utilization of TEEAL databases in the University of Calabar Library. Evidence from table 3 indicated that fewer number of the respondent from the various departments of the Faculty of Agriculture have utilized TEEAL database to a very large extent for research / teaching. The result showed that lecturer I (5) have utilized TEEAL to a very large extent, followed by lecturer 11 (4) senior lecturer (3), while the least academic staff utilizing TEEAL is Asso. professor (1). And no professor is utilizing TEEAL. The results conformed to the work of Ani and Edem (2012) in the extent of access and use of online databases by academics in the University of Calabar, Nigeria. The finding of the study indicate that although academic staff are accessing and using relevant databases in teaching and research, the frequency of usage is rather very low as most lecturers are not aware of the e- resources in the university libraries. This report calls for concern about the lecturers to endeavor to visit the library and enquire on the electronic resources available for use in research and teaching.
Table 3. Extent of utilization of TEEAL databases by respondents in ranking order.

\begin{tabular}{lllll}
\hline Respondents & VLE & LE & SE & NA \\
\hline Asst. Lecturer & 2 & 2 & 5 & - \\
Lecturer II & 4 & 3 & 3 & - \\
Lecturer I & 5 & 4 & 5 & - \\
Senior lecturer & 3 & 3 & 5 & - \\
Asso. professor & 1 & 2 & 5 & - \\
Professor & - & 3 & 5 & - \\
\hline
\end{tabular}

VLE: Very large extent

LE: large Extent

SE: small Extent

NA: Not available

\subsection{Frequency of Utilization of TEEAL Databases by Respondents in the University Library}

The respondents were asked to indicate their frequency of utilization of TEEAL databases in the University of Calabar library. According to Ani, Ngulebe and onyancha (2015), frequency of utilization is an important dimension in the use of electronic resources. Foster, Heppensta, Lazarz and Broug (2008) had revealed a low access and use of electronic resources by academic staff in Nigerian Universities which have affected their research output.

The results in table 4 showed frequency of utilization of TEEAL database by the respondents in teaching/research. It is observed that most of the respondents are utilizing TEEAL "occasionally" (46.7\%), this is followed by weekly users $(23.3 \%)$ and only $(6.7 \%)$, are daily users. The result indicated low frequency of utilization of TEEAL database by academic staff from the faculty studied. The reason may likely be lack of awareness and training skills on the utilization of the database as reported by (Egberongbe, 2011; Ani and Edem, 2012.) Foster et al (2012) have found out that the frequency of access and usage of electronic resources in teaching of research in the university is rather low which has affected their research output.

Table 4. Frequency of utilization of TEEAL database by respondents.

\begin{tabular}{lll}
\hline Frequency & Response & \% \\
\hline Daily & 4 & 6.7 \\
Weekly & 14 & 23.3 \\
Monthly & 8 & 13.3 \\
Occasionally & 28 & 46.7 \\
Never & 6 & 10.0 \\
\hline
\end{tabular}

The respondents were asked to indicate their opinion of TEEAL databases for teaching and research. The result on table 5 showed that $(80.0 \%)$ of the respondents strongly agreed that they are able to use abstracts from TEEAL to do their research work. (53.3\%) responded that TEEAL databases gives a better research output, while (50.0\%) believed that TEEAL gives them an insight to the various topics for lectures. (50.0\%) of respondents can search TEEAL databases using the index term, and (50.0\%) observed that TEEAL contains an update of information on the various topic for research. The researcher noticed with 
dismay the attitude of lecturers from faculty of Agriculture that their frequency utilization of TEEAL database in the university library is rather very low as they occasionally $(46.7 \%)$ use TEEAL the library. The reason behind this is that TEEAL database can only be found at the e-library in a dedicated computer meant for library users, while lecturers resort to online search in their various offices.

Table 5. Assessment of TEEAL databases for teaching and research.

\begin{tabular}{|c|c|c|c|c|}
\hline Opinion & SA (\%) & A (\%) & DA (\%) & SD (\%) \\
\hline TEEAL gives one an insight to the various topics for lectures and research. & $30(50.0)$ & $15(25.0)$ & $10(16.7)$ & $5(8.3)$ \\
\hline I am able to search for subject areas using TEEAL index term & $30(50.0)$ & $15(25.0)$ & $10(16.7)$ & $5(8.3)$ \\
\hline TEEAL gives me better research output & $32(53.3)$ & $14(23.3)$ & $12(20.0)$ & $2(3.3)$ \\
\hline I am able to use the abstracts for my research and publication & $48(80.0)$ & $12(20.0)$ & $-(00.0)$ & $-(00.0)$ \\
\hline I am conversant with the topics listed in TEEAL (CD-ROM) & $28(46.7)$ & $22(36.6)$ & $10(16.7)$ & $-(00.0)$ \\
\hline
\end{tabular}

Strongly agree: SA

Agree: A

Disagree: DA

Strongly Disagree: SD

Table 6. Challenges Associated with the use of TEEAL databases for research and teaching.

\begin{tabular}{|c|c|c|c|}
\hline $\mathbf{S} / \mathbf{N}$ & $\begin{array}{l}\text { Challenges associated with the use of } \\
\text { TEEAL }\end{array}$ & Frequency & $\%$ \\
\hline 1 & Lack of time to spend on searching & 53 & $88.3 \%$ \\
\hline 2 & Lack of training on how to search & 55 & 91.7 \\
\hline 3 & $\begin{array}{l}\text { I don't know how to use TEEAL in the } \\
\text { library }\end{array}$ & 52 & 86.7 \\
\hline 4 & Improper orientation & 55 & 91.7 \\
\hline 5 & $\begin{array}{l}\text { Lack of awareness of its availability in the } \\
\text { university library }\end{array}$ & 57 & 95.0 \\
\hline 6 & Frequent power failure & 55 & 91.7 \\
\hline 7 & No assistance whenever I want to use TEEAL & 52 & 88.7 \\
\hline 8 & Lack of access to TEEAL databases & 56 & 93.3 \\
\hline
\end{tabular}

\subsection{Challenges Associated with the Use of TEEAL for Research and Teaching}

Respondents were asked to indicate the challenges associated with the use of TEEAL for teaching and research. As shown in table 6, the respondents had multiple choice responses to the questions asked. The result showed lack of awareness of its availability $(95.0 \%)$ in the university library as the major reason. Others ranging from lack of access to TEEAL databases $(93.3 \%)$, lack of training on how to search (91.7\%), improper orientation (91.7\%), and frequent power failure $(91.7 \%)$, lack of time to spend on searching $(88.3 \%)$ and no assistance in the library (88\%). The result showed that nearly all the respondents were not utilizing TEEAL provided by the university library. This could be attributed to lack of awareness and training on how to use TEEAL databases provided by the university. The problem of lack awareness and lack of training were also reported by Egberongbe (2011) and Lawal and Lawal (2015) in their study as factors affecting accessibility of database in most universities. In another instance, the respondents usually access TEEAL from different sources outside the library which helps them to do their research effectively.

\subsection{Ways to Proffer Solution}

Table 7 below contains multiple choice responses to the questions asked. The result showed that user's awareness campaign $(95.0 \%)$ should be carried by management/staff of the library through writing of memos, sending e-mails or text messages to lecturers in the various departments concerning the availability of TEEAL databases in the university library. Training users on how to search and use TEEAL databases in the e-library (73.3\%), constant power supply (91.7\%) and proper orientation programme $(93.3 \%)$ should be organized from time to time in the University library.

Table 7. Ways to Proffer Solution.

\begin{tabular}{lll}
\hline Item & Frequency & $\mathbf{\%}$ \\
\hline $\begin{array}{l}\text { User awareness campaign } \\
\text { (e-mail, text messages) memos) etc. }\end{array}$ & 57 & 95.0 \\
$\begin{array}{l}\text { Access to TEEAL databases } \\
\begin{array}{l}\text { Training users on how to search and use TEEAL } \\
\text { databases. }\end{array}\end{array}$ & 56 & 93.3 \\
$\begin{array}{l}\text { Constant power supply } \\
\text { Proper orientation programme }\end{array}$ & 55 & 91.7 \\
Allocating time for search in the library & 56 & 93.3 \\
\hline
\end{tabular}

\section{Conclusion}

Most academic lecturers from faculty of Agriculture are not aware of the wealth of agricultural information stored in CD-ROM available in the e-library of the university of Calabar library for users' utilization. TEEAL database contains an up- to -date information on agriculture which is very useful for research and teaching, but the utilization by academic staff in the faculty of Agriculture seems to be very low due to lack of awareness, lack of proper training, and lack of access to the database in the university library. The paper reports that users' awareness campaign should be carried out by staff of the university on the availability of TEEAL and other acquired databases. Academic librarians 
should carry out contentious orientation on both staff and students using the e-library for effective utilization of the databases and should also allocate time for proper search of the resources in the library. Most importantly, there should be constant power supply and internet access for library users for effective and sustainable access to databases in the elibrary.

\section{References}

[1] Aina, L. O. (2012) The Information environment for agricultural stakeholders in Botswana. Information Development, 28 (2): 149-159.

[2] Ani, Okon E.; Ngulube, Patrick and Onyancha, Bosire (2014). Effect of accessibility and Utilization of electronic information resources on productivity of academic staff in selected Nigerian universities. Available at http://www.sciencepublishing group.com/j/sr

[3] Ani, Okon and Edem, Nkoyo (2012) Access and usage of online databases in Nigerian Universities in teaching/research. Library and Information Practitioner 5 (1 \& 2), 475-486.

[4] Bashorun, M., Tunji, I. A. \& Adisa, M. U. (2011). User perception of electronic resources in the University of Illorin, Nigeria. Journal of emerging trends in computing and information sciences 2 (11): 554-562.
[5] Bhatt, S. \& Rana, M. S. (2011) E-information usage among engineering academics in India with special reference to Rajasthan state. Library hi tech. 29 (3): 496-511.

[6] Chuckwusa, J. (2015) Electronic resources usage in some selected university libraries in south south, Nigeria.

[7] Edem, N. B. and Ani, O. E (2015) Development of Electronic libraries in Nigerian Universities. Information Technologist, $12(2), 35-45$

[8] Edem, Nkoyo (2015) Utilization of information Technology Facilities for Research by undergraduate students in Nigerian Tertiary Institutions. Information and knowledge Management, 5 (10) 81-87, Available online at http://www.iitse.org/journals/index.php/....

[9] Egberongbe, H. S. (2011) The use and impact of electronic resources at the university of lagos. Library philosophy and practice (e-journal) paper 472. Retrieved February 2, 2016 from

http://digitalcommons.uni.edu/cgi/newcontent.cgi;article=149 \&context $=$ hbphilprac.

[10] Foster, K.; Heppensta, R.; Lazarz, C. \& Broug, E. (2008). Emerald academy 2008 authorship in Africa. Available at http://info.emeraldinsight.com/pdf/report.pdf/.20.3.14

[11] Lawal, M. T. and Lawal, B. (2015). Information Literacy Skills and accessibility of databases among undergraduate students of Umaru Musa yar'adua University, katsina. Information Technologist, vol 12 (2), 95-105. 